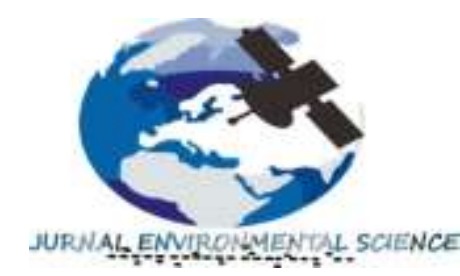

Jurnal Environmental Science

Volume 3 Nomor 2 April 2021

p-ISSN : 2654-4490 dan e-ISSN : 2654-9085

Homepage at : ojs.unm.ac.id/JES

E-mail:jes@unm.ac.id

\title{
ANALISIS PENGARUH APHELION DAN PERIHELION TERHADAP SUHU MENGGUNAKAN WEATHER STATION
}

\author{
*Abu Yazid Raisal ${ }^{1}$, Hariyadi Putraga ${ }^{2}$, Muhammad Hidayat ${ }^{3}$, Arwin Juli Rakhmadi ${ }^{4}$ \\ Universitas Muhammadiyah Sumatera Utara, Jalan Denai No. 217 Medan, Indonesia \\ *Email: abuyazidraisal@gmail.com
}

\begin{abstract}
The Sun is the main source of energy for life on Earth. Long-term changes in solar activity play an important role in global climate change. Climate change causes the temperature to rise and fall on the Earth's surface. The Sun's rays carry the energy and even radiation. The total radiation received on the Earth's surface is influenced by the distance of the Sun, the intensity of solar radiation, and the length of the day. The Sun's distance always changes throughout the year because the Earth's orbit around the Sun is elliptical. The Sun's closest distance from the Earth is known as perihelion. The Sun's furthest distance from the Earth is known as aphelion. This study aims to determine the effect of aphelion and perihelion on the temperature in the Medan city using a weather station. Aphelion and perihelion do not have a significant impact on Earth's temperature. When the Earth is closest to the Sun (perihelion), the Earth's temperature is lower than when the Earth is farthest from the Sun. Earth's temperature is slightly higher in July because the northern part of the planet Earth, which is densely populated with land, is tilted towards the Sun, where land warms faster than the oceans. In addition, the temperature on the Earth's surface is also influenced by wind patterns.
\end{abstract}

Keywords: Aphelion, Perihelion, Weather Station.

\section{ABSTRAK}

Matahari merupakan sumber energi utama bagi kehidupan di Bumi. Perubahan aktifitas Matahari jangka panjang memegang peranan penting dalam perubahan iklim global. Perubahan iklim tersebut menyebabkan naik turunnya suhu di permukaan bumi. Pancaran cahaya Matahari tersebut membawa energi bahkan radiasi. Total radiasi yang diterima dipermukaan bumi dipengaruhi oleh jarak Matahari, intensitas radiasi Matahari, panjang hari. Jarak Matahari selalu berubah sepanjang tahun dikarenakan orbit Bumi mengelilingi Matahari berbentuk elips. Saat Bumi berada pada jarak terdekat dengan Matahari disebut perihelion. Saat Bumi berada pada jarak terjauh dari Matahari disebut aphelion. Penelitian ini bertujuan untuk mengetahui pengaruh aphelion dan perihelion terhadap suhu di kota Medan menggunakan weather station. Aphelion dan perihelion tidak memiliki dampak yang signifikan terhadap suhu Bumi. Ketika jarak Bumi paling dekat dengan Matahari (perihelion), suhu Bumi justru lebih rendah dibandingkan dengan saat jarak Bumi paling jauh dengan Matahari. Suhu Bumi sedikit lebih tinggi pada bulan Juli dikarenakan bagian utara planet Bumi yang padat akan daratan lebih condong ke arah Matahari, dimana daratan lebih cepat panas dibandingkan dengan lautan. Selain itu suhu di permukaan Bumi juga dipengaruhi oleh pola angin.

Kata Kunci: Aphelion, Perihelion, Weather Station 


\section{PENDAHULUAN}

Sejak berjuta tahun yang lalu Bumi sudah berkali-kali mengalami perubahan iklim. Selain itu, aktifitas manusia dan faktor alamiah menyebabkan perubahan iklim dengan memberikan dampak yang berbeda-beda. Perubahan iklim tersebut menyebabkan naik turunnya suhu di permukaan bumi (Sarinda et al., 2017). Perubahan iklim global juga dapat dipengaruhi oleh perubahan aktifitas Matahari jangka Panjang. Matahari merupakan sumber energi utama bagi kehidupan di Bumi. Ketika aktifitas Matahari meningkat, maka jumlah energi yang dipancarkan ke bumi akan semakin besar (Susatya et al., 2011). Pancaran cahaya Matahari tersebut membawa energi bahkan radiasi. Radiasi Matahari merupakan pancaran energi yang berasal dari proses thermonuklir yang terjadi di Matahari, konsentrasi radiasi Matahari memiliki aktivitas tinggi ketika siang hari pada saat cuaca cerah (sekitar jam 07:00 s/d jam 15:00 wib). Radiasi Matahari yang sampai ke permukaan Bumi dapat dipengaruhi oleh beberapa faktor. Posisi Matahari dan kedudukan wilayah di permukaan Bumi berpengaruh terhadap potensi radiasi Matahari di suatu wilayah (Rifai et al., 2014).

Radiasi Matahari akan mengalami hambatan yang disebabkan oleh partikel-partikel yang ada di atmosfer. Hambatan tersebut berupa serapan, hamburan, dan pantulan (Mairisdawenti et al., 2014). Radiasi tersebut dipantulkan kembali ke angkasa dalam bentuk gelombang panjang, sebagian gelombang tersebut diserap oleh gas rumah kaca, yaitu $\mathrm{CO}_{2}, \mathrm{CH}_{4}, \mathrm{~N}_{2} \mathrm{O}$, HFCs dan $\mathrm{SF}_{4}$ yang berada di atmosfer. Akibatnya gelombang panjang yang bersifat panas tersebut terperangkap di dalam atmosfer bumi. (Syaifullah, 2016). Radiasi Matahari akan mengalami perubahan ketika adanya penghalang seperti adanya awan atau hujan. Jumlah total radiasi yang diterima dipermukaan bumi dipengaruhi oleh jarak Matahari, intensitas radiasi Matahari, panjang hari (sun duration), dan pengaruh atmosfer. Selain dari 4 faktor tersebut intensitas radiasi Matahari dipengaruhi adanya intensitas hujan harian. Kandungan uap air ketika turun hujan akan menutup cahaya Matahari yang masuk pada sensor radiasi. (Subiakto, 2016).

Jarak Matahari selalu berubah sepanjang tahun dikarenakan orbit Bumi mengelilingi Matahari berbentuk elips. Sehingga adakalanya Bumi berada pada jarak terdekat dan terjauh dengan Matahari. Saat Bumi berada pada jarak terdekat dengan Matahari disebut perihelion dengan jarak Bumi terhadap Matahari sebesar 146,6 juta kilometer. Saat Bumi berada pada jarak terjauh dari Matahari disebut aphelion dengan jarak Bumi terhadap Matahari sebesar 152,65 juta kilometer seperti terlihat pada gambar 1. Jarak rata-rata Bumi terhadap Matahari adalah 150 juta kilometer atau 1 Satuan Astronomi (1 SA) (Raisal \& Rakhmadi, 2020). Variasi jarak Matahari dengan Bumi sebesar 3\%. Hal ini berpengaruh terhadap diameter sudut Matahari yang terlihat dari Bumi (Sopwan, 2018).

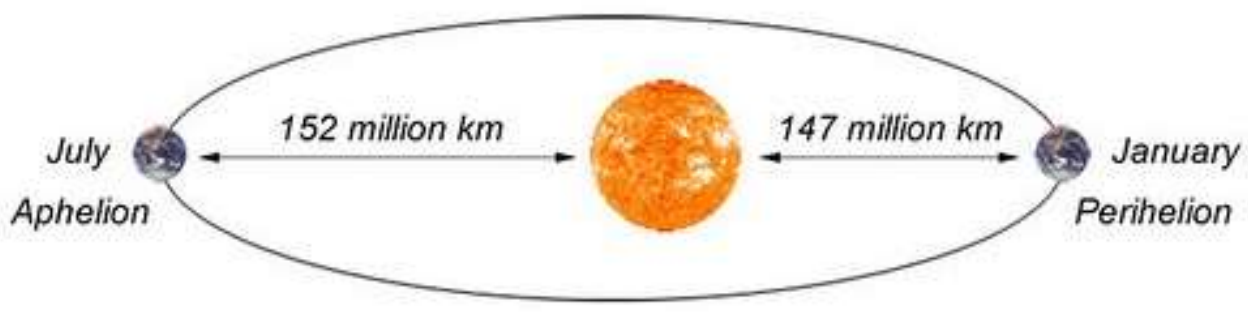

Gambar 1. Orbit Bumi

Suhu udara meliputi dua aspek yaitu derajat dan insolasi atau intensitas radiasi Matahari yang sampai ke permukaan bumi dimana salah satu yang mempengaruhi insolasi adalah ketinggian suatu lokasi dari permukaan laut. Semakin tinggi kedudukan suatu tempat, suhu udara di tempat tersebut akan semakin rendah, begitu juga sebaliknya semakin rendah kedudukan suatu tempat, suhu udara akan semakin tinggi (Sitorus et al., 2014). Suhu rata-rata Bumi meningkat disebabkan oleh pemanasan global yang berasal dari efek rumah kaca (Partiwi, 2019). Dampak pemanasan global antara lain perubahan curah hujan, naiknya intensitas badai, mencairnya es di kutub, menyebakan penurunan variasi hayati laut, dan lain-lain (Latuconsina, 2010).

Suhu udara dapat diukur dengan berbagai cara seperti menggunakan termometer dinding maupun weather station. Weather station merupakan sebuah instrumen yang digunakan untuk 
memantau cuaca. Proses pemantauan cuaca yang konvensional menggunakan beberapa perangkat sensor yang terpasang pada suatu modul dan terpasang pada suatu tempat (Saefullah et al., 2015). Sensor yang biasanya terdapat pada Weather Station adalah sensor suhu, kecepatan angin, curah hujan, dan kelembaban udara. Penelitian ini bertujuan untuk mengetahui pengaruh aphelion dan perihelion terhadap suhu menggunakan weather station.

\section{METODE}

Sumber data suhu udara diperoleh menggunakan alat Professional Wireless Weather Station (PWWS) dari MISOL. Selain mengukur suhu udara, alat ini juga dapat mengukur kecepatan angin, curah hujan, dan kelembaban udara. PWWS dipasang di anjungan Observatorium Ilmu falak Universitas Muhammadiyah Sumatera Utara (OIF UMSU) yang berada pada koordinat $3^{\circ} 34^{\prime} \mathrm{LU}$ dan $98^{\circ} 43^{\prime}$ BT. Penempatan PWWS harus ditempat terbuka dan jauh dari bangunan gedung atau pepohonan yang dapat menghalangi angin, hujan ataupun cahaya Matahari yang masuk pada sensor. Penelitian dilakukan di Observatorium Ilmu falak Universitas Muhammadiyah Sumatera Utara (OIF UMSU) yang berlokasi di gedung pascasarjana Universitas Muhammadiyah Sumatera Utara jalan Denai No. 217 pada koordinat $3^{\circ} 34^{\prime}$ LU dan $98^{\circ} 43^{\prime}$ BT. Pengambilan data dilakukan pada saat perihelion bulan Januari dan aphelion bulan Juli.

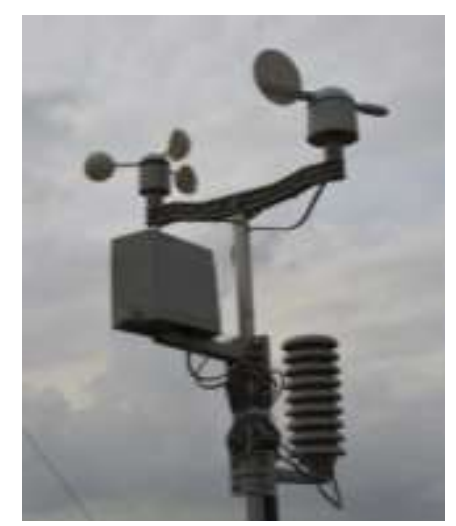

Gambar 2. Professional Wireless Weather Station

Sumber data suhu udara diperoleh menggunakan alat Professional Wireless Weather Station (PWWS) dari MISOL. PWWS dipasang di anjungan yang berada di tempat terbuka dan berada di lokasi paling tinggi seperti terlihat pada gambar 2 .

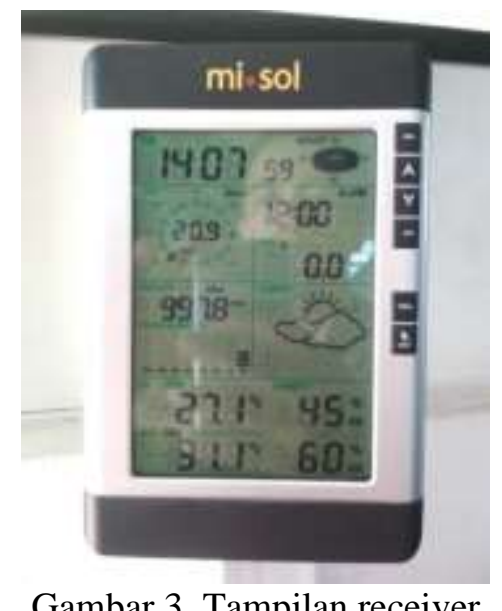

Data suhu yang dipilih pada saat Matahari memiliki aktivitas tinggi ketika siang hari yaitu pukul 07.00 - 15.00. Data dari PWWS diterima oleh receiver yang dipasang di dalam ruangan seperti 
terlihat pada gambar 3. Selanjutnya data dari reciever dipindahkan ke dalam PC menggunakan kabel USB. Data dipindahkan menggunakan aplikasi Easyweather seperti terlihat pada gambar 4.

Metode pengolahan, pengambilan dan analisa data dilakukan dengan cara memperlakukan data sebagai berikut:

1. Melakukan export data menjadi bentuk excel

2. Melakukan penyuntingan data suhu dengan data yang lain

3. Mencari rata-rata suhu harian

4. Membandingkan suhu pada saat perihelion dan aphelion

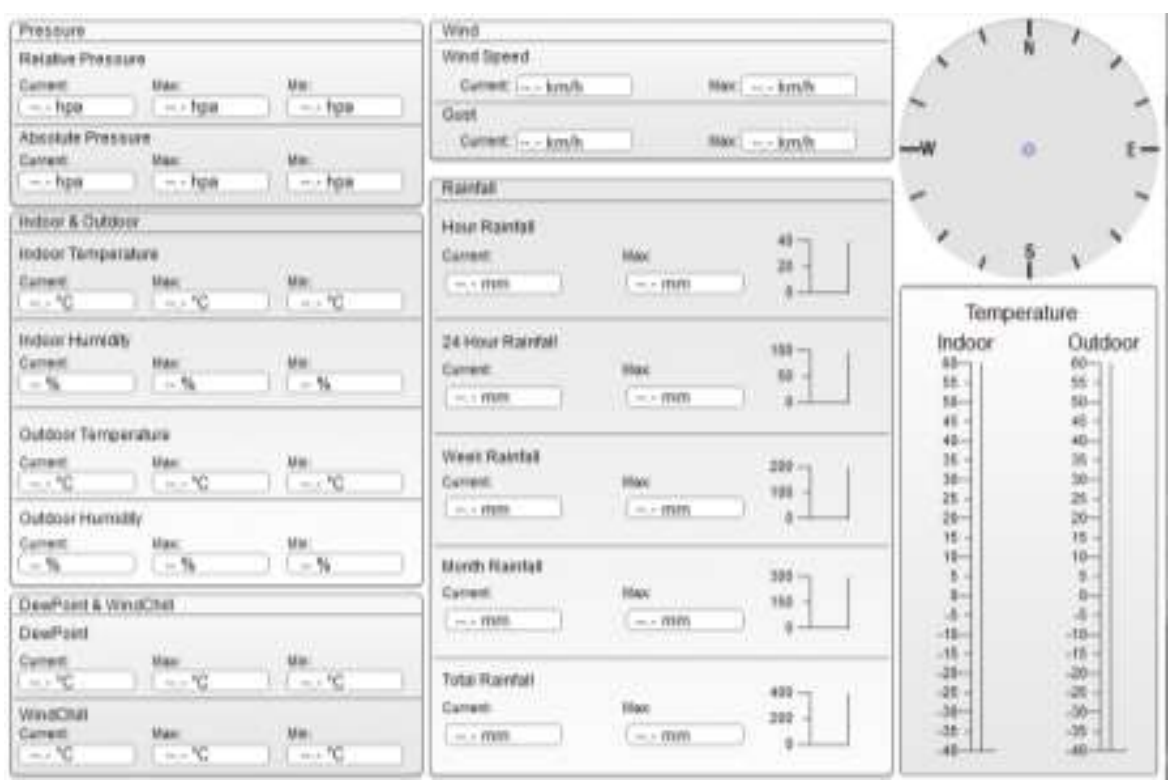

Gambar 4. Tampilan Easyweather

\section{HASIL DAN PEMBAHASAN}

\section{Hasil}

Data yang digunakan pada penelitian ini adalah ketika aphelion tanggal 4 Juli 2020 dan perihelion tanggal 2 Januari 2021. Selain itu ditambahkan data lima hari setelah dan lima hari sebelum aphelion atau perihelion. Sehingga data yang digunakan pada saat aphelion dan perihelion sebanyak sebelas hari hari. Data suhu yang dipilih pada saat Matahari memiliki aktivitas tinggi ketika siang hari yaitu pukul $07.00-15.00$.

Tabel 1. Data suhu saat aphelion

\begin{tabular}{cc}
\hline Tanggal & Suhu $\left({ }^{\mathbf{} C e l s i u s}\right)$ \\
\hline $29 / 06 / 2020$ & 32,54 \\
$30 / 06 / 2020$ & 30,81 \\
$01 / 07 / 2020$ & 30,33 \\
$02 / 07 / 2020$ & 31,06 \\
$03 / 07 / 2020$ & 30,48 \\
$04 / 07 / 2020$ & 31,34 \\
$05 / 07 / 2020$ & 30,70 \\
$06 / 07 / 2020$ & 24,96 \\
$07 / 07 / 2020$ & 29,65 \\
$08 / 07 / 2020$ & 31,56 \\
$09 / 07 / 2020$ & 28,53 \\
\hline
\end{tabular}


Data suhu saat aphelion diambil sepuluh hari dari tanggal 29 Juni 2020 hingga 9 Juli 2020 seperti terlihat pada tabel 1 . Data suhu tersebut merupakan suhu rata-rata saat Matahari memiliki aktivitas tinggi ketika siang hari yaitu pukul $07.00-15.00$.

Tabel 2. Data suhu saat perihelion

\begin{tabular}{cc}
\hline Tanggal & Suhu $\left({ }^{\mathbf{0}}\right.$ Celsius $)$ \\
\hline $28 / 12 / 2020$ & 30,01 \\
$29 / 12 / 2020$ & 26,51 \\
$30 / 12 / 2020$ & 29.25 \\
$31 / 12 / 2020$ & 28,21 \\
$01 / 01 / 2021$ & 27,55 \\
$02 / 01 / 2021$ & 26,98 \\
$03 / 01 / 2021$ & 25,11 \\
$04 / 01 / 2021$ & 28,87 \\
$05 / 01 / 2021$ & 28,45 \\
$06 / 01 / 2021$ & 25,69 \\
$07 / 01 / 2021$ & 28,32 \\
\hline
\end{tabular}

Data suhu saat perihelion diambil sepuluh hari dari tanggal 28 Desember 2020 hingga 7 Januari 2021 seperti terlihat pada tabel 2. Data suhu tersebut merupakan suhu rata-rata saat Matahari memiliki aktivitas tinggi ketika siang hari yaitu pukul $07.00-15.00$.

Sebelum menguji apakah ada perbedaan yang sinifikan terhadap dua kelompok data suhu tersebut, terlebih dahulu dilakukan uji normalitas dan uji homogenitas pada masing-masing kelompok data. Berdasarkan uji normalitas data diperoleh hasil bahwa data suhu pada saat perihelion berdistribusi normal. Sementara data suhu pada saat aphelion tidak berdistribusi normal dikarenakan nilai signifikannya sebesar 0.04 lebih kecil daripada nilai taraf kepercayaan sebesar 0,05 seperti terlihat pada tabel 3 .

Tabel 3. Hasil uji normalitas data

\begin{tabular}{cccc}
\hline Jarak Matahari & Taraf Signifikansi & Signifikansi & Kesimpulan \\
\hline Aphelion & 0.05 & 0.04 & Tidak Normal \\
Perihelion & 0.05 & 0.20 & Normal \\
\hline
\end{tabular}

Data aphelion tidak berdistribusi normal diakibatkan karena ada data yang terlalu ekstrem rendah. Dari pengecekan data, diperoleh bahwa data suhu pada tanggal 6 Juli 2020 merupakan data yang ekstrem rendah sehingga kelompok data aphelion berdistribusi tidak normal. Pada hari tersebut terjadi hujan sepanjang hari dari pukul 09.00 WIB hingga pukul 15.00 WIB.

Untuk mengatasi kelompok data yang tidak berdistribusi normal, data yang ektrem rendah pada tanggal 6 Juli 2020 dibuang. Jumlah data untuk aphelion setelah data yang ekstrem rendah tidak dipakai menjadi sepuluh data. Setelah terjadi pengurangan data, kelompok data aphelion menjadi berdistribusi normal seperti terlihat pada tabel 4 .

Tabel 4. Hasil uji normalitas data setelah dilakukan pengurang data

\begin{tabular}{cccc}
\hline Jarak Matahari & Taraf Signifikansi & Signifikansi & Kesimpulan \\
\hline Aphelion & 0.05 & 0.20 & Normal \\
Perihelion & 0.05 & 0.20 & Normal \\
\hline
\end{tabular}

Setelah dilakukan uji normalitas, data selanjutnya dilakukan uji homogenitas data. Dari uji homogenitas data, diperoleh hasil bahwa data tersebut homogen karena nilai signifikansinya lebih tinggi daripada 0,05 seperti terlihat pada tabel 5 . 
Tabel 5. Hasil uji homogenitas data

\begin{tabular}{cccc}
\hline Tes homogen & Taraf Signifikansi & Signifikansi & Kesimpulan \\
\hline Based on Mean & 0.05 & 0.82 & Homogen \\
\hline
\end{tabular}

Setelah data berdistribusi normal, maka dilakukan uji hipotesis menggunakan uji $\mathrm{T}$ untuk mengetahui pengaruh jarak terhadap suhu permukaan. Setelah dilakukan uji T, diperoleh bahwa nilai signifikansi lebih kecil dari taraf signifikansi sebesar 0,05 seperti terlihat pada tabel 6. Oleh karena itu, dapat disimpulkan bahwa jarak memiliki pengaruh yang signifikan terhadap suhu permukaan. Namun, suhu yang lebih tinggi terjadi ketika aphelion atau ketika Bumi berada pada jarak terjauh dari Matahari dengan suhu rata-rata sebesar $30,70^{\circ} \mathrm{C}$. Sedangkan pada saat perihelion atau ketika Bumi berada pada jarak terdekat dari Matahari, suhu permukaan lebih rendah dengan suhu rata-rata sebesar $27,72^{\circ} \mathrm{C}$.

Tabel 6. Hasil uji T

\begin{tabular}{cccc}
\hline df & Taraf Signifikansi & Signifikansi & Kesimpulan \\
\hline 19 & 0.05 & 0.00 & $\mathrm{H}_{0}$ ditolak \\
\hline
\end{tabular}

\section{Pembahasan}

Menurut Roy Spencer dari Pusat Hidrologi dan Iklim Global di Huntsville, Alabama, suhu rata-rata Bumi di aphelion sekitar 2,3 ${ }^{\circ} \mathrm{C}$ lebih tinggi daripada di perihelion. Hal ini disebabkan benua dan samudera tidak didstribusikan secara merata di seluruh dunia. Ada lebih banyak daratan di belahan bumi utara dan lebih banyak air di selatan. Selama bulan Juli, ketika aphelion, bagian utara planet Bumi yang padat akan daratan lebih condong ke arah Matahari. Suhu Bumi sedikit lebih tinggi pada bulan Juli dikarenakan Matahari menyinari daratan yang ada di belahan Bumi utara, dimana daratan lebih cepat panas dibandingkan dengan lautan (NASA Science, 2001).

Kemampuan daratan untuk menyimpan energi panas adalah rendah. Ketika terjadi radiasi Matahari, daratan cepat menjadi panas. Sebaliknya di waktu tidak tejadi radiasi Matahari, yang terjadi di malam hari atau di musim dingin, daratan cepat menjadi dingin (Hasanudin, 1997). Secara umum, aphelion dan perihelion Bumi tidak memberikan dampak yang signifikan terhadap Bumi. Ketika belahan Bumi utara lebih condong ke Matahari, tekanan udara di belahan Bumi utara lebih rendah dibandingkan dengan belahan Bumi selatan yang sedang mengalami musim dingin. Hal ini menyebabkan angin bergerak dari arah selatan menuju arah utara. Dampak yang ditimbulkan adalah terjadinya penurunan suhu untuk sekitar Indonesia, karena angin dari arah Australia yang sedang mengalami musim dingin bergerak menuju arah utara melintasi Indonesia. Panas dari Matahari didistribusikan ke seluruh permukaan Bumi, dengan distribusi yang paling signifikan mempengaruhi adalah pola angin (Pangerang, 2020).

\section{SIMPULAN}

Pada saat aphelion dan perihelion diperoleh suhu rata-rata sebesar $30,70^{\circ} \mathrm{C}$ dan $27,72^{\circ} \mathrm{C}$. Berdasarkan uji $\mathrm{T}$, diperoleh bahwa jarak Matahari berpengaruh terhadap suhu permukaan Bumi. Namun, suhu yang lebih tinggi terjadi saat aphelion atau atau ketika Bumi berada pada jarak terjauh dari Matahari. Ketika jarak Bumi paling dekat dengan Matahari (perihelion), suhu Bumi justru lebih rendah dibandingkan dengan saat jarak Bumi paling jauh dengan Matahari. Suhu Bumi sedikit lebih tinggi pada saat aphelion dikarenakan bagian utara planet Bumi yang padat akan daratan lebih condong ke arah Matahari, dimana daratan lebih cepat panas dibandingkan dengan lautan. Selain itu, suhu di permukaan Bumi juga dipengaruhi oleh pola angin. Pada saat aphelion, angin dari arah Australia yang sedang mengalami musim dingin bergerak menuju arah utara melintasi Indonesia. Hal ini mengakibatkan suhu di sekitar Indonesia menjadi lebih dingin. Dari beberapa pernyataan yang telah dikemukakan, dapat disimpulkan bahwa aphelion dan perihelion tidak memiliki dampak yang signifikan terhadap suhu Bumi. 


\section{DAFTAR PUSTAKA}

Hasanudin, M. (1997). Pengaruh Laut terhadap Iklim. Oseana, 22(2), 15-22.

Latuconsina, H. (2010). Dampak Pemanasan Global Terhadap Ekosistem Pesisir dan Lautan. Agrikan: Jurnal Agribisnis Perikanan, 3(1), 30-37. https://doi.org/10.29239/j.agrikan.3.1.30-37

Mairisdawenti, Pujiastuti, D., \& Ilahi, A. F. (2014). Analisis Pengaruh Intensitas Radiasi Matahari, Temperatur dan Kelembaban Udara Terhadap Fluktuasi Konsentrasi Ozon Permukaan di Bukit Kototabang Tahun 2005-2010. Jurnal Fisika Unand, 3(3), 177-183.

NASA Science. (2001). Aphelion Away! Science.Nasa.Gov. https://science.nasa.gov/sciencenews/science-at-nasa/2001/ast03jul_1

Pangerang, A. (2020). Bersiaplah, 4 Juli Terjadi Fenomena Aphelion. Http://Edukasi.Sains.Lapan.Go.Id. http://edukasi.sains.lapan.go.id/artikel/bersiaplah-4-juliterjadi-fenomena-aphelion/229

Partiwi, A. (2019). Pengenalan Pemicu Pemanasan Global Menggunakan Teknologi Augmented Reality Berbasis Desktop. Jurnal Ilmiah Teknologi Dan Rekayasa, 24(1), 46-57. https://doi.org/10.35760/tr.2019.v24i1.1933

Raisal, A. Y., \& Rakhmadi, A. J. (2020). Understanding the effect of revolution and rotation of the earth on prayer times using accurate times. Ulul Albab: Jurnal Studi Dan Penelitian Hukum Islam, 4(1), 81-101.

Rifai, L. D., Tongkukut, S. H. J., \& Raharjo, S. S. (2014). Analisis Intensitas Radiasi Matahari di Manado dan Maros. Jurnal MIPA, 3(1), 49-52. https://doi.org/10.35799/jm.3.1.2014.3907

Saefullah, A., Sunarya, A., \& Fakhrizal, D. (2015). Prototype Weather Station Berbasis Arduino Yun. CCIT Journal, 8(2), 57-65. https://doi.org/10.33050/ccit.v8i2.317

Sarinda, A., Sudarti, \& Subiki. (2017). Analisis Perubahan Suhu Ruangan Terhadap Kenyamanan Termal di Gedung 3 FKIP Universitas Jember. Jurnal Pembelajaran Fisikia, 6(3), 305-311.

Sitorus, T. B., Napitupulu, F. H., \& Ambarita, H. (2014). Korelasi Temperatur Udara dan Intensitas Radiasi Matahari Terhadap Performansi Mesin Pendingin Siklus Adsorpsi Tenaga Matahari. Jurnal Ilmiah Teknik Mesin Cylinder, 1(1), 8-17.

Sopwan, N. (2018). Citra matahari ektrim utara dan ekstrim selatan sebagai pembelajaran pergerakan matahari. Prosiding Seminar Nasional Fisika, 33-36.

Subiakto, T. (2016). Selisih Rerata Radiasi Matahari Bulanan Musim Panas dan Hujan Hasil Observasi Tahun 2015 di Balailapan Pasuruan. Prosiding SNPBS (Seminar Nasional Pendidikan Biologi Dan Saintek) Ke-1, 2, 242-248.

Susatya, E. K. A., Pamungkas, R., Susanti, T., \& Setiawan, A. (2011). Pengukuran Radiasi Matahari Dengan Memanfaatkan Sensor Suhu LM35. Prosiding Seminar Nasional Sains Dan Pendidikan Sains UKSW, 1-5.

Syaifullah, M. D. (2016). Suhu Permukaan Laut Perairan Indonesia dan Hubungannya Dengan Pemanasan Global. Jurnal Segara, 11(2), 103-113. 